\title{
HUBUNGAN MOTIVASI BELAJAR DAN KECERDASAN INTELEKTUAL DENGAN HASIL BELAJAR PAI DI SD NEGERI WILAYAH 5 SAENTIS DELI SERDANG
}

\author{
Nurliana Pohan \\ Penulis adalah SD Negeri Wilayah 5 Saentis Deli Serdang
}

\begin{abstract}
Abstrak
This study aims to examine the relationship between learning motivation and intellectual intelligence with learning outcomes both individually and together. The population of this study amounted to 272 students, a sample of 98 people. Learning motivation data using a Likert scale questionnaire. The intellectual intelligence of students is tested, learning outcomes are obtained through report cards. The results of the first hypothesis analysis are $15.5 \%$. The second hypothesis is $10.04 \%$. The third hypothesis is $27.46 \%$. the remaining $72.54 \%$ is influenced by other variables not measured in this study.
\end{abstract}

\section{Kata kunci: Motivasi Belajar, Kecerdasan Intelektual, Hasil Belajar}

\section{PENDAHULUAN}

Masalah yang berhubungan dengan pendidikan, terutama isu mutu lulusan masih menjadi topik menarik untuk didiskusikan dan tak kunjung terselesaikan sampai saat ini. Masalah mutu pendidikan masih menjadi persoalan dari mulai tingkat pendidikan dasar sampai dengan perguruan tinggi, di mana mutu lulusan yang dihasilkan oleh lembaga pendidikan saat ini dianggap banyak pihak tidak memiliki kemampuan fungsional di tengah perubahan yang serba cepat dan mekanistis. Dikatakan menarik, karena mutu pendidikan dapat dijadikan sebagai indikator penentu kemajuan peradaban suatu bangsa. Dalam kehidupan sehari-hari dengan mudahnya ditemukan berbagai sikap dan perilaku menyimpang yang disengaja dipertontonkan secara sengaja di ruang-ruang publik. Indikasikasi ini menguatkan dugaan bahwa pendidikan agama saat ini mulai usang dan bahkan ditinggalkan oleh masyarakat yang terbius dengan perubahan yang dibawa modernisasi.

Undang-undang Sistem Pendidikan Nasional nomor 20 tahun 2003 pasal 1 ayat 1 dinyatakan bahwa: Pendidikan adalah usaha sadar dan terencana untuk menciptakan suasana belajar dan proses pembelajaran agar peserta didik secara aktif mengembangkan potensi dirinya, untuk memiliki kekuatan spiritual keagamaan, pengendalian diri, kepribadian, kecerdasan, akhlaq mulia, serta keterampilan yang diperlukan dirinya, masyarakat, bangsa, dan negara. Berdasarkan rumusan makna 
pendidikan itu, dapat ditegaskan bahwa aspek yang berkaitan dengan spiritual keagamaan menjadi faktor pertama dan utama yang harus ada serta dikembangkan dalam diri siswa melalui proses pembelajaran.

Berdasarkan studi dokumentasi yang penulis lakukan terhadap hasil belajar PAI siswa pada beberapa SD di Kabupaten Deli Serdang dapat dikategorikan baik. Secara empirik, capaian hasil belajar siswa SD di Kabupaten Deli Serdang dapat ditunjukkan melalui capaian hasil belajar semester genap tahun pelajaran 2016/2017 dalam tiga tahun berturut-turut dengan perolehan nilai antara 85 - 97.

Penelitian yang dilakukan Darling-Hammond, et.al (2007:15), tentang Preparing School Leaders for a Changing World: Lessons from Exemplary Leadership Development Programs mengemukakan faktor-faktor yang mempengaruhi hasil belajar siswa, yaitu: latarbelakang keluarga, kondisi sekolah, kondisi guru, kemampuan guru, dan kemampuan siswa.

\section{KAJIAN TEORETIK}

\section{Hakikat Belajar dan Hasil Belajar}

Gagne mendefinisikan belajar adalah: (1) belajar adalah suatu proses untuk memperoleh motivasi dalam pengetahuan, keterampilan, kebiasaan dan tingkah laku. (2) belajar adalah penguasaan pengetahuan atau keterampilan yang diperoleh melalui instruksi. Gagne (dalam Slameto, 1995:27), untuk mengenali apa yang dimaksud dengan belajar dapat dilihat ciri-ciri penting dari belajar: (1) belajar adalah proses di mana manusia dapat melakukannya, (2) belajar pada umumnya melibatkan interaksi dengan lingkungan eksternal, dan (3) belajar dapat terjadi bila suatu perubahan atau modifikasi perilaku terjadi, dan perubahan itu tetap dalam massa yang relatif lama pada kehidupan individu.

Winkel (1999:37), memberi definisi belajar yang lebih bersifat komprehensif yaitu suatu proses dari belum mampu menjadi mampu. Menurut penulis, definisi ini dianggap memiliki nilai fungsional, karena dengan belajar siswa akan mampu/dapat melakukan suatu pekerjaan/aktivitas yang sebelumnya ia tidak/belum mampu untuk melakukannya.

Snellbecker (1974:76), mengidentifikasikan perubahan tingkahlaku yang diperoleh melalui belajar yang dapat dilihat pada ciri-ciri sebagai berikut: (a) terbentuknya tingkahlaku baru yang berupa kemampuan aktual maupun potensial, (b) 
kemampuan itu berlaku dalam waktu yang relatif lama, dan (c) kemampuan baru itu diperoleh melalui usaha. Belajar adalah suatu fenomena atau gejala yang dapat langsung diamati, gejala tersebut hanya dapat diduga dari tingkahlaku atau penampilan seseorang.

Sedangkan hasil belajar menurut menyatakan bahwa adalah penilaian pendidikan tentang kemampuan siswa setelah melalui aktivitas belajar dalam kurun waktu yang ditentukan (Gredler, 1991:12). Berdasarkan pada defenisi ini dapat dipahami bahwa hasil belajar adalah penilaian terhadap kemampuan siswa yang ditentukan dalam bentuk angka-angka atau nilai. Tujuan pembelajaran merupakan hasil yang akan dicapai melalui proses belajar. Bloom (dalam Slameto, 1995:23), mengemukakan taksonomi tujuan pembelajaran ke dalam tiga ranah yaitu ranah kognitif, afektif, dan psikomotorik.

\section{Motivasi Belajar}

Steers dan Porter (1991:56), istilah motivasi berasal dari bahasa Latin, yaitu movere yang berarti menggerakkan. Istilah motivasi berasal dari kata motif yang dapat diartikan sebagai kekuatan yang terdapat dalam diri individu, yang menyebabkan individu tersebut bertindak atau berbuat. Motif tidak dapat diamati secara langsung, tetapi dapat diinterpretasikan dalam tingkahlakunya, berupa rangsangan, dorongan, atau pembangkit tenaga munculnya suatu tingkah laku tertentu.

Motivasi juga merupakan konstruk yang meliputi aspek tujuan atau kebutuhan, keinginan untuk mencapai tujuan, dan nilai potensial hasil atau imbalan. Motivation is also a construct that covers significant goal or need, desire to/attain the goal, perception that learning is relevant to fulfilling the goal or meeting the need, belief in likely success or failure of learning, and value of potential outcomes /rewards. Berdasarkan pada definisi tersebut dapat dinyatakan bahwa motivasi dapat tumbuh dalam diri seseorang karena pada diri yang bersangkutan terdapat tujuan atau keinginan yang ingin dicapai sehingga muncul dorongan untuk mencapainya. Begitu juga dalam aktivitas belajar, apabila siswa selalu diberi rangsangan berupa hadiah (rewards), maka siswa tersebut akan lebih giat dalam belajarnya.

Karena itu, motivasi merupakan salah satu komponen terpenting dalam mencapai hasil pembelajaran dalam bidang PAI. Apabila dalam diri siswa terdapat keinginan untuk belajar PAI, hal ini berarti dalam dirinya muncul kesediaan untuk 
mengerahkan seluruh upaya untuk belajar PAI. Hamalik (2008:158), menyatakan ada dua prinsip yang dapat digunakan untuk meninjau motivasi ialah: (1) motivasi dipandang sebagai suatu proses. Pengetahuan tentang proses ini akan membantu untuk menjelaskan perilaku yang diamati dan untuk memperkirakan kelakuan-kelakuan lain pada seseorang. (2) menentukan karakter dari proses ini dengan melihat petunjukpetunjuk dari tingkah lakunya. Apakah petunjuk-petunjuk dapat dipercaya, dapat dilihat kegunaannya dalam memperkirakan dan menjelaskan tingkahlaku lainnya.

Steers dan Porter (1987:78), menyatakan ada tiga aspek motivasi yang dapat diidentifikasi. Pertama, motivasi menggambarkan sebuah kekuatan atau energi seseorang yang mampu menggerakkan atau menyebabkan seseorang berperilaku dalam kegiatan tertentu. Apabila seseorang telah termotivasi, maka ia akan melakukan suatu pekerjaan dengan sungguh-sungguh. Kedua, gerakan ini langsung bertujuan pada suatu hal yaitu motivasi yang mempunyai orientasi tujuan yang kuat (strong objectives). Seseorang yang memiliki motivasi tinggi, maka ia akan melakukan suatu pekerjaan dengan sekuat tenaga agar tujuan yang diinginkan dapat tercapai. Ketiga, membantu mempertahankan semangat kerja sepanjang waktu.

Motivasi belajar adalah keinginan yang sungguh-sungguh untuk melakukan aktivitas belajar yang membuat dirinya memperoleh hasil maksimal, dengan indikatorindikator: (a) tekun menghadapi tugas (dapat bekerja terus-menerus dalam waktu yang lama, tidak pernah berhenti sebelum selesai, (b) ulet menghadapi kesulitan (tidak cepat putus asa). Tidak memerlukan dorongan dari luar untuk berprestasi sebaik mungkin (tidak cepat puas dengan prestasi yang telah dicapainya, (c) menunjukkan minat yang tinggi terhadap bermacam-macam masalah, (d) lebih senang belajar mandiri, (e) tidak mudah melepaskan hal yang diyakini itu, (f) cepat bosan pada tugas-tugas yang rutin (hal-hal yang bersifat mekanis, berulang-ulang begitu saja, sehingga kurang kreatif, (g) dapat mempertahankan pendapatnya (kalau sudah yakin akan sesuatu, dan (h) senang mencari dan memecahkan masalah.

\section{Kecerdasan Intelektual (Intellectual Quotient)}

Anastasi (1981) yang mengutip pendapat Stren, menjelaskan bahwa intelegensi adalah merupakan kemampuan untuk mengetahui problem serta kondisi baru, kemampuan berpikir abstrak, kemampuan bekerja, kemampuan menguasai tingkah laku instinktif, serta kemampuan menerima hubungan yang kompleks. Studard 
menginterpretasikan intelegensi sebagai kecakapan untuk melaksanakan satu aktivitas yang ditandai oleh (1) kesukaran; (2) kekomplekan; (3) keabstrakan; (4) ekonomis; (5) penyesuai ke arah tujuan; (6) mempunyai nilai sosial; dan (7) bersifat asli. Pendapat lain dikemukakan Vernon (1960) berusaha membuat penggabungan pandangan yang berbeda-beda mengenai intelegensi, dan merumuskannya sebagai kemampuan untuk melihat hubungan yang relevan diantara objek-objek atau gagasan-gagasan serta kemampuan untuk menerapkan hubungan itu ke dalam situasi baru yang serupa.

Kolesnik (dalam Slameto, 1995:12), "in most cases there is a fairly high correlation between one's IQ, and his scholastik success. Usually, the higher a person's $I Q$, the higher the grades he receives". Berdasarkan ungkapan ini, dapat diduga bahwa tingkat intelegensi merupakan faktor yang menentukan berhasil tidaknya siswa di sekolah. Pengetahuan mengenai tingkat intelegensi siswa akan membantu guru menentukan apakah siswa mampu mengikuti pelajaran, serta meramalkan keberhasilan atau gagalnya siswa yang bersangkutan bila telah mengikuti pengajaran yang diberikan. Integensi dapat diukur dengan tes intelegensi. Woodwort dan Marquis yang dikutip oleh Suryabrata (1984) adalah: di atas 140 luar biasa; 120-139 cerdas sekali, 110-119 cerdas, 90-109 sedang, dan 80-89 bodoh.

\section{METODE PENELITIAN}

Jenis penelitian ini adalah kuantitatif dengan desain penelitian expost facto. Penelitian expost facto bertujuan untuk menguji apa yang telah terjadi. Hajar (1996:26) penelitian expost facto bertujuan untuk mengetahui apakah perbedaan yang terjadi antar kelompok subjek. Penelitian ini dilaksanakan dengan pola kajian korelatif dengan mengklasifikasikan variabel penelitian ke dalam dua kelompok, yaitu variabel bebas dan variabel terikat. Populasi dalam penelitian ini siswa SD Negeri wilayah 5 Saentis. Berdasarkan hasil perhitungan penarikan besar sampel diperoleh sebanyak 98 orang siswa $(36 \%)$.

\section{HASIL PENELITIAN}

\section{Motivasi Belajar $\left(X_{1}\right)$}

Pengolahan data variabel motivasi belajar menunjukkan skor terendah 100 dan tertinggi 124. Skor minimal 57 dan skor maksimal 228. Hasil perhitungan dari distribusi data diperoleh rata-rata (mean) 111.70., simpangan baku 5.019., median 
111.00., dan modus sebesar 111.00. Distribusi frekuensi variabel motivasi belajar dapat sebagai berikut:

\begin{tabular}{|l|c|c|c|c|c|}
\hline \multirow{2}{*}{ MOTIVASI BELAJAR } & \multicolumn{4}{|c|}{ Statistics } \\
\cline { 3 - 6 } & Frequency & Percent & Valid Percent & $\begin{array}{c}\text { Cumulative } \\
\text { Percent }\end{array}$ \\
\hline \multirow{3}{*}{ Valid } & $98,5-102,5$ & 2 & 2.9 & 2.9 & 2.9 \\
\hline & $102,5-106,5$ & 6 & 8.7 & 8.7 & 11.6 \\
\hline & $106,5-110,5$ & 31 & 30.4 & 30.4 & 42.0 \\
\hline & $110,5-114,5$ & 29 & 27.5 & 27.5 & 69.6 \\
\hline & $114,5-118,5$ & 25 & 23.2 & 23.2 & 92.8 \\
\hline & $118,5-122,5$ & 4 & 5.8 & 5.8 & 98.6 \\
\hline & $122,5-126,5$ & 1 & 1.4 & 1.4 & 100.0 \\
\cline { 2 - 6 } & Total & 98 & 100.0 & 100.0 & \\
\hline
\end{tabular}

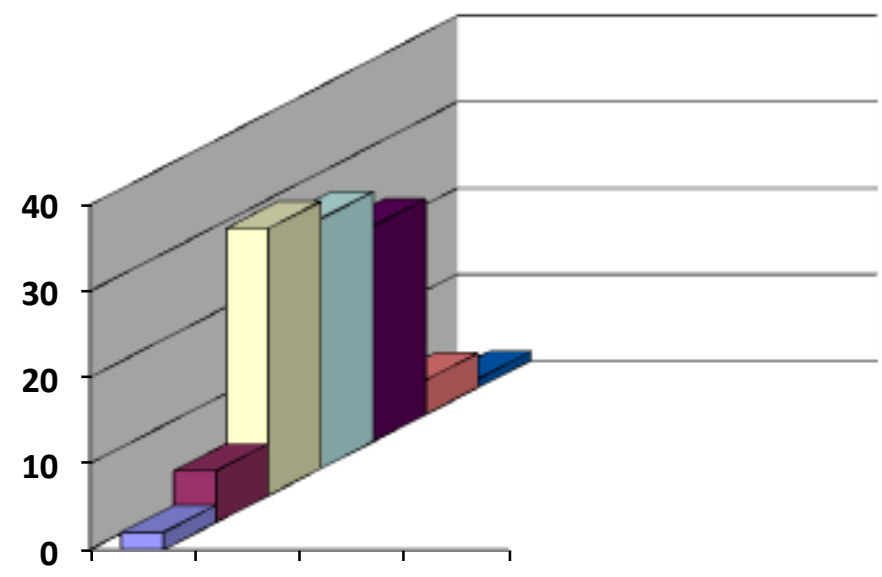

\section{Histogram Variabel Motivasi Belajar}

Pengelompokkan motivasi belajar dibagi menjadi tiga kelompok, yakni: tinggi, sedang dan rendah. Kategori rendah 39 orang (39,80\%), sedang 29 orang (29,59\%), dan tinggi 30 orang (30.61\%). Dapat disimpulkan bahwa motivasi belajar secara umum berada pada kelompok sedang.

\section{Kecerdasan Intelektual}

Pengolahan data kecerdasan intelektual menunjukkan skor terendah 75 dan tertinggi 120. Menghasilkan rata-rata (mean) 94.26., simpangan baku 5.311., median 94.01., dan modus 94.00. Dari data tersebut menunjukkan rata-rata hitung, median, dan modus tidak jauh berbeda. Distribusi frekuensi variabel kecerdasan intelektual dapat dilihat berikut ini: 


\begin{tabular}{|c|c|c|c|c|c|}
\hline \multirow{2}{*}{\multicolumn{2}{|c|}{$\begin{array}{l}\text { KECERDASAN } \\
\text { INTELEKTUAL } \\
\left(\mathrm{X}_{2}\right)\end{array}$}} & \multicolumn{4}{|c|}{ Statistics } \\
\hline & & \multirow{2}{*}{$\begin{array}{c}\text { Frequency } \\
4\end{array}$} & \multirow{2}{*}{$\begin{array}{c}\text { Percent } \\
5.8\end{array}$} & \multirow{2}{*}{$\begin{array}{c}\text { Valid Percent } \\
5.8\end{array}$} & \multirow{2}{*}{$\begin{array}{c}\begin{array}{c}\text { Cumulative } \\
\text { Percent }\end{array} \\
5.8\end{array}$} \\
\hline Valid & $75-82$ & & & & \\
\hline & 83- 80 & 6 & 8.7 & 8.7 & 14.5 \\
\hline & $81-88$ & 28 & 26.1 & 26.1 & 40.6 \\
\hline & $89-96$ & 35 & 29.0 & 29.0 & 69.6 \\
\hline & $97-104$ & 18 & 20.3 & 20.3 & 89.9 \\
\hline & $105-112$ & 6 & 8.7 & 8.7 & 98.6 \\
\hline & $113-120$ & 1 & 1.4 & 1.4 & 100.0 \\
\hline & Total & 98 & 100.0 & 100.0 & \\
\hline
\end{tabular}

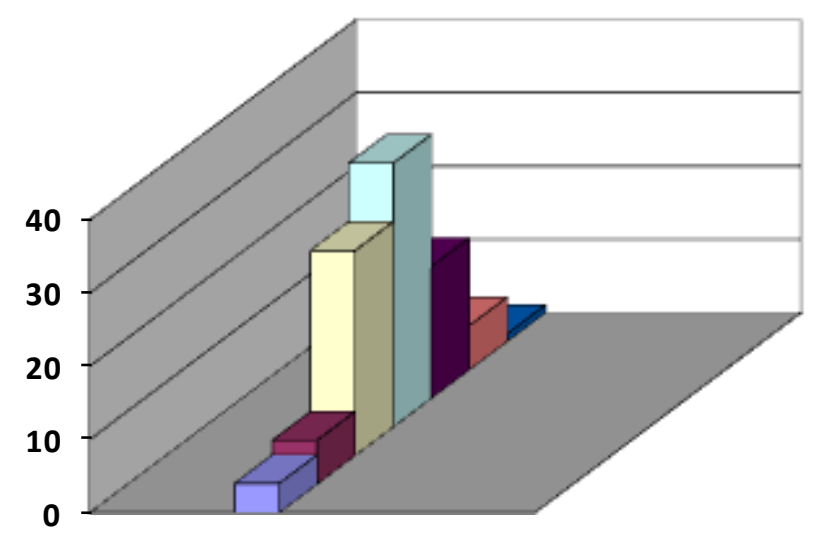

\section{Histogram Variabel Kecerdasan Intelektual}

Variabel kecerdasan intelektual dapat bagi menjadi tiga kategori tinggi, sedang dan rendah. Diperoleh 38 orang (38,78\%) rendah, 35 orang $(35.71 \%)$ sedang, dan 25 orang (25.52\%) tinggi. Disimpulkan bahwa kecerdasan intelektual pada umumnya berada pada kelompok sedang.

\section{Hasil Belajar Siswa (Y)}

Perhitungan data diperoleh rata-rata (mean) 83.76., simpangan baku 6.373., median 82.96., dan modus 83.56. Distribusi frekuensi data variabel hasil belajar dapat dilihat berikut ini: 


\section{Distribusi Frekuensi Data Variabel Hasil Belajar}

\begin{tabular}{|l|l|c|c|c|c|}
\hline \multicolumn{2}{|c|}{ KINERJA GURU (Y) } & \multicolumn{4}{c|}{ Statistics } \\
\cline { 3 - 6 } & Frequency & Percent & Valid Percent & $\begin{array}{c}\text { Cumulative } \\
\text { Percent }\end{array}$ \\
\hline \multirow{3}{*}{ Valid } & $66-70$ & 4 & 5.8 & 5.8 & 5.8 \\
\cline { 2 - 6 } & $71-75$ & 8 & 11.6 & 11.6 & 17.4 \\
\hline & $76-80$ & 32 & 31.9 & 31.9 & 49.3 \\
\hline & $81-85$ & 35 & 24.6 & 24.6 & 73.9 \\
\hline & $86-90$ & 13 & 17.4 & 17.4 & 91.3 \\
\cline { 2 - 6 } & $91-95$ & 4 & 5.8 & 5.8 & 97.1 \\
\cline { 2 - 6 } & $96-100$ & 2 & 2.9 & 2.9 & 100.0 \\
\hline & Total & 98 & 100.0 & 100.0 & \\
\hline
\end{tabular}

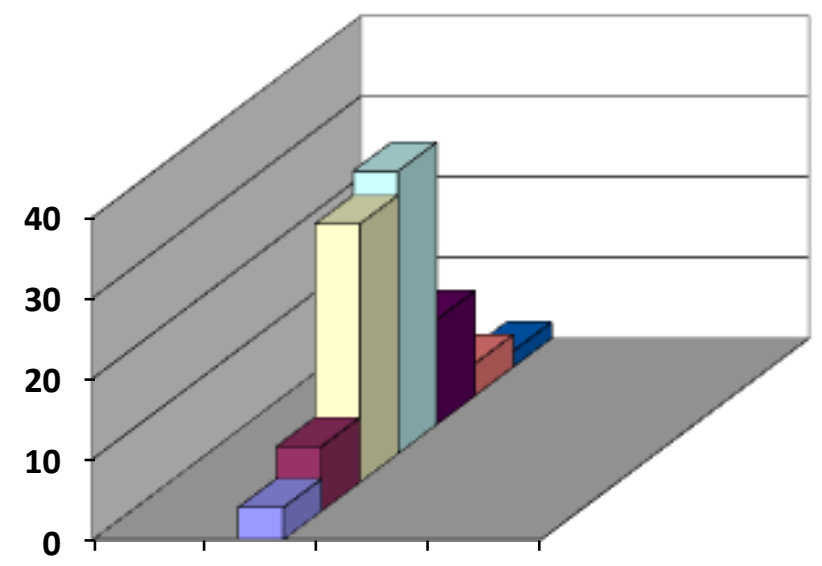

\section{Histogram Variabel Hasil Belajar}

Frekuensi data hasil belajar dapat dibagi menjadi tinggi, sedang dan rendah. Diperoleh 44 orang siswa SD (44.90\%) rendah, 35 orang siswa SD (35.71\%) sedang, dan 19 orang siswa SD (19.39\%) tinggi. Disimpulkan bahwa hasil belajar pada umumnya berada pada kelompok sedang.

\section{Pengujian Persyaratan Analisis}

\section{Uji Normalitas}

\begin{tabular}{|l|c|c|c|}
\hline \multirow{2}{*}{\multicolumn{1}{|c|}{ Statistik }} & \multicolumn{3}{|c|}{ Variabel } \\
\cline { 2 - 4 } & $\left(\mathrm{X}_{1}\right)$ & $\left(\mathrm{X}_{2}\right)$ & 98 \\
\hline $\mathrm{N}$ & 98 & 98 & 133.28 \\
\hline Normal parameter a.b & 111,70 & 121.71 & 5.373 \\
\hline
\end{tabular}




\begin{tabular}{|l|c|c|c|}
\hline Std. deviation & & & \\
\hline Most Extreme & 091 & 091 & 072 \\
Differences & 091 & 091 & 072 \\
Absolute & -0.59 & -0.59 & -053 \\
Positive & & & \\
Negative & 0.759 & 0.486 & 0.599 \\
\hline Kolmogorov-Smirnov & & & 866 \\
Z & 612 & 972 & \\
\hline Asymp. Sig. (2-tailed) & & & \\
\hline
\end{tabular}

\section{Uji Linearitas Garis Regresi}

\section{a. Uji Linearitas Garis Regresi Y Terhadap $\mathrm{X}_{1}$}

ANOVA Table

\begin{tabular}{|c|c|c|c|c|c|c|c|}
\hline \multirow{2}{*}{\multicolumn{2}{|c|}{$\begin{array}{l}\text { Dependent Variable * } \\
\text { Independent Variable }\end{array}$}} & \multirow[b]{2}{*}{ Source } & \multicolumn{5}{|c|}{ Statistics } \\
\hline & & & \multirow{2}{*}{$\begin{array}{c}\text { Sum of } \\
\text { Squares } \\
1115.519\end{array}$} & \multirow{2}{*}{$\begin{array}{l}\text { df } \\
20\end{array}$} & \multirow{2}{*}{$\begin{array}{l}\text { Mean } \\
\text { Square } \\
55.776\end{array}$} & \multirow{2}{*}{$\begin{array}{c}F \\
1.626\end{array}$} & \multirow{2}{*}{$\begin{array}{l}\text { Sig. } \\
.085\end{array}$} \\
\hline HASIL BELAJAR Y & Between & (Combined) & & & & & \\
\hline \multirow{4}{*}{$\begin{array}{l}\text { MOTIVASI BELAJAR } \\
\left(\mathrm{X}_{1}\right)\end{array}$} & Groups & Linearity & 428.631 & 1 & 428.631 & 12.498 & .001 \\
\hline & & $\begin{array}{l}\text { Deviation from } \\
\text { Linearity }\end{array}$ & 686.889 & 19 & 36.152 & 1.054 & .424 \\
\hline & \multicolumn{2}{|c|}{ Within Groups } & 1646.249 & 88 & 34.297 & & \\
\hline & \multicolumn{2}{|l|}{ Total } & 2761.768 & 98 & & & \\
\hline
\end{tabular}

Hasil uji keberartian persamaan regresi sederhana diperoleh $F_{\text {hitung }}$ 1.054., sedangkan $\mathrm{F}_{\text {tabel }}$ pada $\alpha={ }_{0.05}$ adalah 3.98 dan $\alpha={ }_{0.01}$ adalah 7.01. $F_{\text {hitung }} \leq \mathrm{F}_{\text {tabel }}$ baik pada nilai $\alpha={ }_{0.05}$ maupun $\alpha={ }_{0.01}$. Disimpulkan motivasi belajar dan hasil belajar membentuk garis lurus (linear).

\section{b. Uji Linearitas Garis Regresi $\mathbf{Y}$ Terhadap $\mathbf{X}_{2}$}

\section{ANOVA Table}

\begin{tabular}{|c|c|c|c|c|c|c|c|}
\hline \multirow[b]{2}{*}{$\begin{array}{l}\text { Dependent Variable * } \\
\text { Independent Variable }\end{array}$} & \multirow{2}{*}{\multicolumn{2}{|c|}{ Source }} & \multicolumn{5}{|c|}{ Statistics } \\
\hline & & & $\begin{array}{l}\text { Sum of } \\
\text { Squares }\end{array}$ & df & $\begin{array}{l}\text { Mean } \\
\text { Square }\end{array}$ & $\mathrm{F}$ & Sig. \\
\hline \multirow{5}{*}{$\begin{array}{l}\text { HASIL BELAJAR }(Y) * \\
\text { KECERDASAN } \\
\text { IN*Z)LEKTUAL }\end{array}$} & \multirow{3}{*}{$\begin{array}{l}\text { Between } \\
\text { Groups }\end{array}$} & (Combined) & 1265.785 & 22 & 57.536 & 1.769 & .051 \\
\hline & & Linearity & 276.677 & 1 & 276.677 & 8.508 & .005 \\
\hline & & $\begin{array}{l}\text { Deviation from } \\
\text { Linearity }\end{array}$ & 989.108 & 21 & 47.100 & 1.448 & .146 \\
\hline & \multicolumn{2}{|c|}{ Within Groups } & 1495.983 & 86 & 32.521 & & \\
\hline & \multicolumn{2}{|l|}{ Total } & 2761.768 & 98 & & & \\
\hline
\end{tabular}

Hasil dari uji keberartian persamaan regresi sederhana diperoleh $\mathrm{F}_{\text {hitung }}$ 1.448., sedangkan $F_{\text {tabel }}$ pada $\alpha={ }_{0.05}$ adalah 3.98 dan $\alpha={ }_{0.01}$ adalah 7.01. $F_{\text {hitung }} \geq F_{\text {tabel }}$ 
baik pada nilai $\alpha={ }_{0.05}$ dan ${ }_{0.01}$. Disimpulkan variabel kecerdasan intelektual dan hasil belajar membentuk garis lurus (linear).

\section{Uji Interdepedensi $X_{1}$ dan $X_{2}$}

\begin{tabular}{|l|l|l|l|l|l|l|l|}
\hline \multirow{2}{*}{ Variabel } & \multirow{2}{*}{$\mathrm{N}$} & \multirow{2}{*}{$\mathrm{r}_{1.2}$} & \multirow{2}{*}{$\mathrm{R}_{1.2}$} & \multirow{2}{*}{$\mathrm{t}_{\text {hitung }}$} & \multicolumn{2}{|c|}{$\mathrm{t}_{\text {tabel }}$} & \multirow{2}{*}{ Simpulan } \\
\cline { 5 - 8 } & & & & & $\alpha=0.05$ & $\alpha=0.05$ & \\
\hline $\mathrm{X}_{1}, \& \mathrm{X}_{2}$ & 98 & 0.195 & 0.0380 & 2.27 & 1.97 & 1.97 & Sig. \\
\hline
\end{tabular}

Koefisien korelasi (r) antar variabel bebas adalah 0.195. Hal ini berarti antar variabel bebas masih terjadi korelasi, namun kekuatan korelasi sangat lemah. Dengan demikian maka masing-masing variabel bebas cukup independen.

\section{Pengujian Hipotesis}

Hipotesis pertama

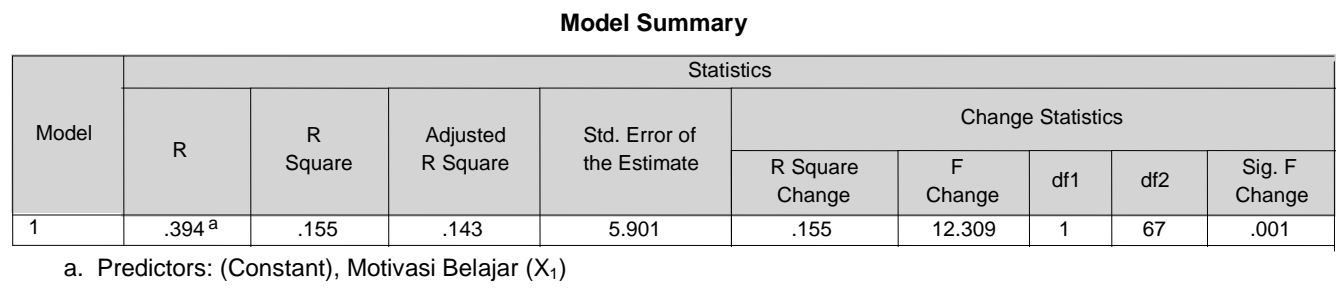

Koefisien korelasi (r) variabel variabel motivasi belajar terhadap hasil belajar PAI adalah 0.394. Koefisien determinasi $\left(\mathrm{R}^{2}\right)$ adalah 0.1552. Dengan demikian berarti bahwa $\mathrm{H}_{1}$ yang menyatakan terdapat kontribusi yang sangat signifikan motivasi belajar terhadap hasil belajar dapat diterima secara empiris, sebagai konsekwensinya $H_{o}$ ditolak.

Hipotesis kedua

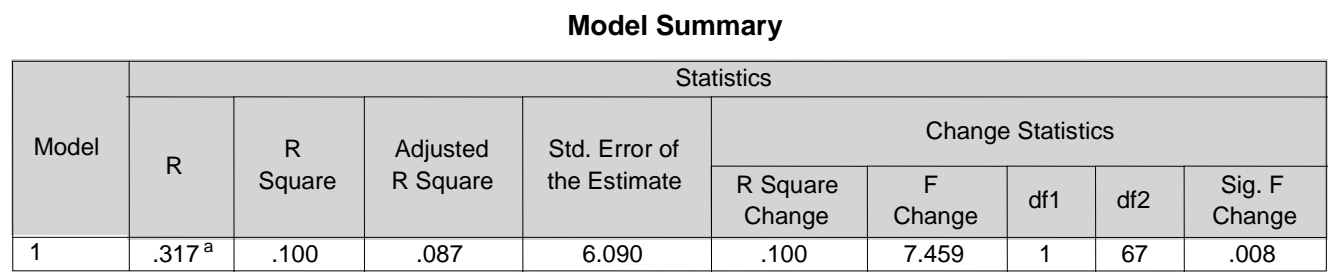

a. Predictors: (Constant), Kecerdasan Intelektual $\left(\mathrm{X}_{2}\right)$

Harga koefisien korelasi (r) variabel kecerdasan intelektual terhadap hasil belajar adalah 0.317. Kekuatan hubungan variabel kecerdasan intelektual terhadap 
hasil belajar $\left(\mathrm{R}^{2}\right)$ adalah 0.1004 . Kontribusinya sebesar $10.04 \%$. Hal ini berarti bahwa $\mathrm{H}_{1}$ yang menyatakan terdapat kontribusi yang sangat signifikan kecerdasan intelektual terhadap hasil belajar telah teruji secara empiris sebagai konsekwensinya $\mathrm{H}_{\mathrm{o}}$ ditolak. Hipotesis ketiga

\begin{tabular}{|c|c|c|c|c|c|c|c|c|c|}
\hline \multicolumn{10}{|c|}{ Model Summary } \\
\hline & \multicolumn{9}{|c|}{ Statistics } \\
\hline & \multirow{2}{*}{$\mathrm{R}$} & \multirow{2}{*}{$\begin{array}{c}\mathrm{R} \\
\text { Square }\end{array}$} & \multirow{2}{*}{$\begin{array}{l}\text { Adjusted } \\
\text { R Square }\end{array}$} & \multirow{2}{*}{$\begin{array}{l}\text { Std. Error of } \\
\text { the Estimate }\end{array}$} & \multicolumn{5}{|c|}{ Change Statistics } \\
\hline & & & & & $\begin{array}{l}\text { R Square } \\
\text { Change }\end{array}$ & $\begin{array}{c}F \\
\text { Change }\end{array}$ & df1 & df2 & $\begin{array}{l}\text { Sig. F } \\
\text { Change }\end{array}$ \\
\hline 1 & $.524^{\mathrm{a}}$ & .274 & .241 & 5.554 & .274 & 8.182 & 3 & 95 & .000 \\
\hline
\end{tabular}

a. Predictors: (Constant), Kecerdasan Intelektual $\left(\mathrm{X}_{2}\right)$, Motivasi Belajar $\left(\mathrm{X}_{1}\right)$

Harga koefisien korelasi (r) motivasi belajar dan kecerdasan intelektual secara bersama-sama dengan hasil belajar adalah 0.52 . Kekuatan hubungan variabel motivasi belajar dan kecerdasan intelektual secara bersama-sama dengan hasil belajar adalah 0.27. Hal ini menunjukkan bahwa hubungan motivasi belajar dan kecerdasan intelektual secara bersama-sama terhadap hasil belajar sangat signifikan. Kekuatan hubungan yang ditunjukkan adalah sebesar 0.52. Pengujian signifikansi regresi ganda dengan menggunakan uji t sebagai berikut:

\section{Kontribusi Masing-Masing Variabel Bebas Terhadap Variabel Terikat}

\begin{tabular}{|c|c|c|c|}
\hline $\begin{array}{c}\text { Variabel } \\
\text { Bebas }\end{array}$ & $\begin{array}{c}\text { Koefisien Korelasi } \\
\left(\mathrm{r}_{\mathrm{xy}}\right)\end{array}$ & $\begin{array}{c}\text { Koefisien Determinasi } \\
\left(\mathrm{R}^{2}\right)\end{array}$ & $\begin{array}{c}\text { Probability } \\
(\mathrm{p})\end{array}$ \\
\hline 1 & 0.394 & 0.1552 & 0.06 \\
2 & 0.317 & 0.100489 & 0.033 \\
\hline
\end{tabular}

\section{PEMBAHASAN DAN DISKUSI HASIL PENELITIAN}

Temuan Pertama. Terdapat hubungan yang signifikan motivasi belajar terhadap hasil belajar PAI siswa SD Negeri di Saentis. Kontribusi yang diberikan oleh variabel motivasi belajar terhadap hasil belajar PAI siswa SD Negeri di Saentis adalah sebesar $15.52 \%$. Hubungan antara variabel motivasi belajar terhadap hasil belajar PAI siswa SD Negeri di Saentis adalah 0.39. Hal ini berarti bahwa apabila faktor motivasi belajar yang ada dalam diri siswa baik motivasi internal (dari dalam diri) maupun motivasi eksternal (dari luar diri siswa) dalam keadaan baik/tinggi, maka hal ini mempengaruhi serta memberikan sumbangan terhadap hasil belajar yang diperoleh 
siswa yang juga akan cenderung baik/tinggi. Sebaliknya, apabila faktor motivasi belajar siswa dalam dirinya rendah/buruk, maka hasil belajarnya juga akan cenderung rendah/tak berkualitas.

Hasil temuan penelitian ini juga sejalan dengan temuan-temuan penelitian sebelumnya, antara lain: Rinehart (dalam Kennedy. P, 1993), faktor motivasi belajar positif yang dimiliki siswa dapat meningkatkan hasil belajar dengan angka korelasi sebesar 0.63. Richard dan Harold (1996) dalam suatu penelitiannya mengemukakan bahwa tingkat korelasi antara motivasi belajar terhadap hasil belajar sebesar 0.56 . Yuniarti (1988) dalam penelitiannya menemukan korelasi kedua variabel motivasi belajar terhadap hasil belajar sebesar 0.4896. Budimarwanto (1991) melakukan penelitian kepada 200 orang siswa swasta di Universitas Islam Negeri Jakarta diperoleh hasil korelasi antara motivasi belajar terhadap hasil belajar sebesar 0.71 . Sementara itu, Nuzlan (1992) memperoleh korelasi sebesar 0.279 pada 150 orang siswa dengan penelitian yang sama yakni tentang korelasi motivasi belajar terhadap hasil belajar.

Persamaan regresi diperoleh $\hat{\mathrm{Y}}=77.396+0.500 \mathrm{X}_{1}$. Berdasarkan persamaan tersebut dapat dijelaskan bahwa terjadi korelasi positif yang mana apabila skor motivasi belajar siswa naik, maka hasil belajar yang diperoleh juga akan naik. Sebagai prediksi dapat dijelaskan pula bahwa jika faktor motivasi belajar siswa meningkat satu skor, maka skor hasil belajar juga akan naik sebesar 0.500. Nilai konstanta intersepsi (a) sebesar 77.396 mengindakasikan bahwa jika nilai koefisien regresi motivasi belajar $\left(\mathrm{bX}_{1}\right)$ tidak terus dinaikkan, maka hasil belajar siswa cenderung menurun bahkan dapat mencapai angka hingga 77.396. Hal ini boleh jadi karena faktor motivasi belajar yang terdapat di dalam diri seseorang siswa akan sangat menentukan hasil belajar yang akan dicapainya.

Temuan Kedua. Terdapat hubungan yang signifikan dari kecerdasan intelektual terhadap hasil belajar. Kontribusi yang disumbangkan oleh variabel kecerdasan intelektual terhadap hasil belajar sebesar $10.04 \%$. Hubungan antara kecerdasan intelektual terhadap hasil belajar adalah sebesar 0.31. Hal ini berarti bahwa apabila kecerdasan intelektual yang dimiliki siswa baik/tinggi, maka hasil belajar juga akan cenderung tinggi/berkualitas. Sebaliknya, apabila motivasi belajar yang dimiliki siswa rendah maka hasil belajar juga akan cenderung rendah/tak berkualitas. 
Persamaan regresi diperoleh $\hat{\mathrm{Y}}=87.052+0.380 \mathrm{X}_{2}$. Berdasarkan persamaan tersebut dapat dijelaskan bahwa terjadi korelasi positif yang mana apabila skor kecerdasan intelektual naik, maka hasil belajar siswa juga akan naik. Sebagai prediksi dapat dijelaskan pula bahwa jika faktor kecerdasan intelektual meningkat satu skor, maka skor hasil belajar akan naik sebesar 0.380. Nilai konstanta intersepsi (a) sebesar 87.052 mengindikasikan bahwa jika nilai koefisien regresi kecerdasan intelektual $\left(\mathrm{bX}_{2}\right)$ tidak terus dinaikkan, maka hasil belajar cenderung menurun bahkan dapat mencapai angka hingga 87.052. Hal ini boleh jadi karena kecerdasan intelektual merupakan faktor internal yang ada dalam diri siswa yang memiliki fungsinya sangat penting dalam kehidupannya. Dengan dasar dan kenyataan ini akan memungkinkan seseorang dapat mengembangkan kemampuannya sehingga dapat tumbuh lebih optimal lagi, termasuk hasil belajarnya.

Temuan ketiga. Terdapat hubungan yang signifikan dari variabel motivasi belajar dan kecerdasan intelektual secara bersama-sama terhadap hasil belajar. Kontribusi yang disumbangkan variabel motivasi belajar dan kecerdasan intelektual secara bersama-sama terhadap hasil belajar adalah $\left(\mathrm{R}^{2}=0.524 \times 100 \%=27.46 \%\right.$. Pengujian hipotesis dengan menggunakan analisis regresi ganda menunjukkan hubungan kedua variabel bebas dalam penelitian ini adalah 0.524 .

Hasil perhitungan persamaan regresi dengan menggunakan analisis regresi berganda diperoleh harga kedua koefisien arah $\left(\mathrm{bX}_{1}\right)$ sebesar 0.395 , dan $\left(\mathrm{bX}_{2}\right) 0.281$ dengan nilai konstanta sebesar 31.985. Dengan demikian persamaan regresinya adalah $\hat{\mathrm{Y}}=31.985+0.395 \mathrm{X}_{1}+0.281 \mathrm{X}_{2}$. hasl ini bermakna bahwa kedua variabel bebas dalam penelitian ini, yakni motivasi belajar dan kecerdasan intelektual sangat penting ditingkatkan secara terus menerus sebagai faktor pendukung utama dalam meningkatkan hasil belajar siswa.

\section{KESIMPULAN}

1. Terdapat hubungan yang signifikan motivasi belajar dengan hasil belajar. Motivasi belajar dan dengan hasil belajar berkorelasi sebesar 0.394. Hal ini berarti bahwa apabila faktor motivasi belajar tinggi, maka dengan hasil belajar cenderung tinggi pula. Kontribusinya sebesar $15.52 \%$.

2. Terdapat hubungan yang signifikan kecerdasan intelektual dengan hasil belajar. Variabel kecerdasan intelektual dengan hasil belajar memiliki korelasi sebesar 
0.317. Hal ini berarti bahwa apabila kecerdasan intelektual yang dimiliki siswa tinggi, maka hasil belajar yang diperoleh juga cenderung akan tinggi. Kontribusinya sebesar 10.04 .

3. Terdapat kontribusi yang signifikan variabel motivasi belajar dan kecerdasan intelektual secara bersama-sama dengan hasil belajar. Hubungan kedua variabel bebas dengan variabel terikat sebesar 0.52. Kontribusi kedua variabel bebas adalah 27.45. Hal ini berarti bahwa kedua variabel bebas dalam penelitian ini berhubungan dan sekaligus memberikan kontribusi yang positif terhadap hasil belajar.

\section{DAFTAR PUSTAKA}

Arikunto, Suharsimi. 1993. Prosedur Penelitian. cetakan keduabelas. Jakarta: Rineka Cipta.

Darling-Hammond, L., LaPointe, M., Meyerson, D., Orr. M. T., \& Cohen, C. (2007), tentang Preparing School Leaders for a Changing World: Lessons from Exemplary Leadership Development Programs. Stanford, CA: Stanford University, Stanford Educational Leadership Institute.

Gagne, Robert., \& Briggs, Lislie. 1979. Principles of Instructional Design. Second Edition. New-York: Holt, Rinehart and Winston.

Gredler M, E. Bell. 1991. Belajar dan Membelajarkan seri Pustaka Teknologi Pendidikan Nomor: 11, Universitas terbuka. Jakarta: Rajawali Pers.

Hajar, Ibnu. 1996. Dasar-Dasar Penelitian Kuantitatif Dalam Pendidikan. Jakarta: Raja Grafindo Persada.

Hamalik, Oemar. 2008. Proses Belajar Mengajar. Cetakan kelima. Jakarta: Bumi Aksara.

Steers, Richard M., dan Porter, Lyman W. 1987. Motivation and Work Behavior. New York: McGrow-Hill Book Company.

Undang-Undang Republik Indonesia Nomor 20 tahun 2003 Tentang Sistim Pendidikan Nasional. Jakarta: Eka Jaya. 